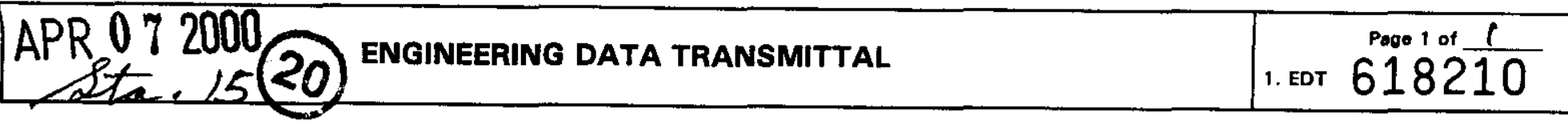

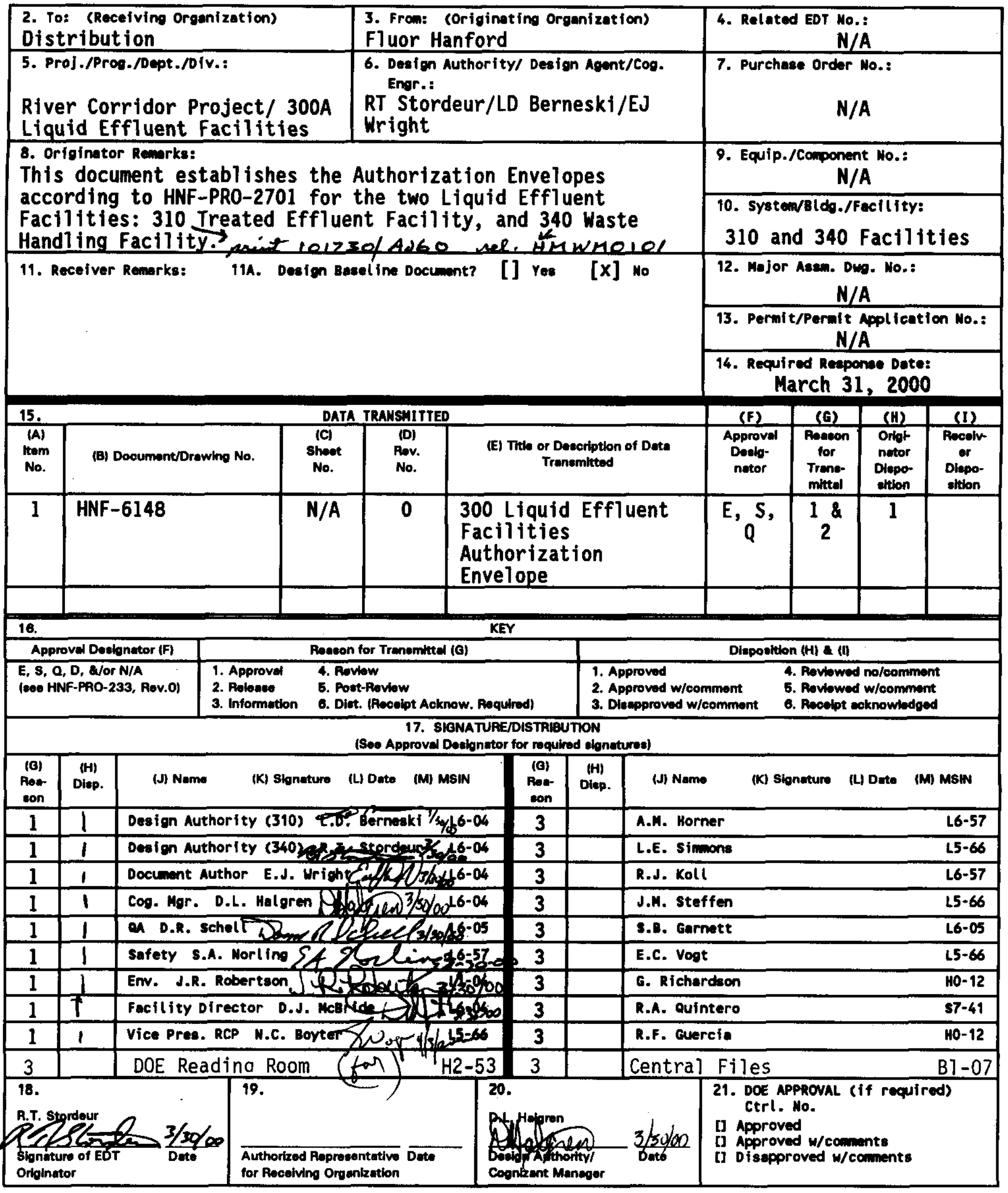

BD-7400-172-2 (10/97) [updated HNF-PRO-233 for WHC-CH-3-5, 12.7] 
$\Omega$

HNF-6148

Revision 0

\section{Area Liquid Effluent Facilities Authorization Envelope}

Prepared for the U.S. Department of Energy

Assistant Secretary for Environmental Management

Project Hanford Management Contructor for the

U.S. Department of Energy under Contract DE-AC06-96RL13200

Fluor Hanford

P.o. Box 1000

Richland, Washington 
HNF-6148

Revision 0

EDT 618210

\section{Area Liquid Effluent Facilities Authorization Envelope}

E. J. Wright

Fluor Hanford, inc.

Date Published

April $\mathbf{2 0 0 0}$

Prepared for the U.S. Department of Energy

Assistant Secretary for Environmental Management

Project Hanford Management Contractor for the

U.S. Department of Energy under Contract DE-AC06-96RL13200

Fuor Hanford

P.O. Box 1000

Richland, Washington

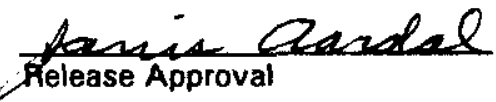

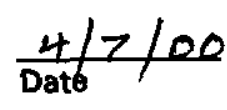

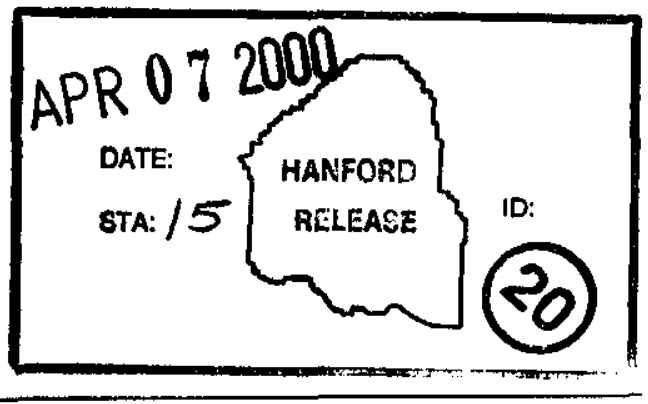

Release Stamp 
HNF-6148

Revision 0

Key Words: $\quad$ Authorization Envelope, AE, Liquid Effluent Facilities, LEF, 300 Area, 310 Facility, 340 Facility, HNF-PRO-2701

\begin{abstract}
The purpose of this document is to establish the facility Authorization Envelope (AE) for the 300 Liquid Effluent Facilities (LEF) Project and identify the requirements related to the maintenance of the AE as specified in HNF-PRO-2701, Authorization Envelope and Authorization Agreement. The 300 LEF Project consists of two separate facilities operating under one management organization. They are the 310 Facility and the 340 Facility. The AE documents the limits of operations for all 300 LEF Project activities.
\end{abstract}


HNF-6148

Rev. 0

\section{TRADEMARK DISCLAMMER}

Reference herein to any speclific commercial product, process,

or service by trade name, trademark, manufacturer, or

otherwise, does not necesearily constitute or Imply its

endorsement, recommendation, or favoring by the United

States Government or any agency thereof or its contractors or subcontractors.

This report has been reproduced from the best available copy.

Printed in the Unitud Statee of Amerion

Total Pages: 10 


\section{HNF-6148 REV. 0 \\ 300 Area Liquid Effluent Facilities Authorization Envelope}

Page 1 of 6

\subsection{PURPOSE}

The purpose of this document is to establish the facility Authorization Envelope (AE) for the 300 Liquid Effluent Facilities (LEF) Project and identify the requirements related to the maintenance of the AE as specified in HNF-PRO-2701, Authorization Envelope and Authorization Agreement.

\subsection{Scope}

The AE documents the limits of operations for all 300 LEF Project activities. The AE identifies the environmental, safety, and health (ES\&H) requirements and controls and the safety basis within which facility operations and activities are authorized. The requirement to prepare an Authorization Envelope is from HNF-MP-003, Integrated Environment, Safety and Health Management System Plan (ISMS), facility-level expectation F33, which requires Major Subcontractors (MSCs) to document and maintain their Authorization Envelopes, including identifying the process to review, approve, and update the $\mathrm{AE}$.

\subsection{Facility Organization}

The 300 LEF Project consists of two separate facilities operating under one management organization. They are the 310 Facility and the 340 Facility. The 310 Facility consists of the 310 Treated Effluent Disposal Facility, 342A Building (waste collection sump), the 307 Waste Retention Basins, 3707-F and the Process Sewer System. The 340 Facility consists of the 340 Waste Handling Facility, which includes the 340, 340-A, and 340-B buildings and the 340 vault/tanks, valve pit, and the Radioactive Liquid Waste System piping network. Both facilities are operated as part of the River Corridor Project (RCP) of Fluor Hanford, Inc.

\subsection{REQUIREMENTS}

HNF-PRO-2701 requires the establishment of processes to:

- Review and approve the AE

- Maintain the AE current

- Perform work in accordance with the AE.

The individual facility AE's are presented in Appendices A \& B.

\subsection{Review Requirements}

The AE shall be reviewed and updated annually, subject to section 2.3 exceptions. The requirement to perform the review will be incorporated into the $300 \mathrm{LEF}$ Project Action/Commitment Tracking System. 
HNF-6148 REV. 0

\section{Area Liquid Effluent Facilities Authorization Envelope}

\subsection{Approval Requirements}

The approval authority for the AE shall be the Vice President, River Corridor Project.

\subsection{Revision Requirements}

The AE shall be revised if new documents are added or documents currently identified as part of the $\mathrm{AE}$ are deleted. Regarding updates to documents and permits already listed, it is advised that they be checked for the most recent revision or version.

\subsection{REFERENCES}

HNF-MP-003, Integrated Environment, Safety, and Health Management System Plan HNF-PRO-2701, Authorization Envelope and Authorization Agreement 
APPENDIX A - Authorization Envelope

\author{
Facility: 310 Treated Effluent Disposal Facility \\ Hazard Categorization: Non-Nuclear, Moderate Hazard \\ Operated by: River Corridor Project
}

\begin{tabular}{|c|c|}
\hline Safety Basis & $\begin{array}{l}\text { Hazard Baseline Documentation } \\
\text { WHC-SD-WM-SAD-025, Rev. 3, Hanford } 300 \text { Area Treated Effluent } \\
\text { Disposal Facility Inventory at Risk Calculations and Safety Analysis } \\
\text { HNF-SD-WM-SAD-027, Rev. 0, Hanford } 300 \text { Area Retention Process Sewer } \\
\text {-Inventory at Risk Calculations and Safety Analysis } \\
\text { - WHC-SD-L045H-FHA-001, Fire Hazard Analysis } \\
\text { WHC-SD-PRP-HA-026, Rev. 1, } 300 \text { Area Treated Effluent Disposal Facility } \\
\text { Hazards Assessment }\end{array}$ \\
\hline $\begin{array}{l}\text { ES\&H Requirements } \\
\text { Basis }\end{array}$ & 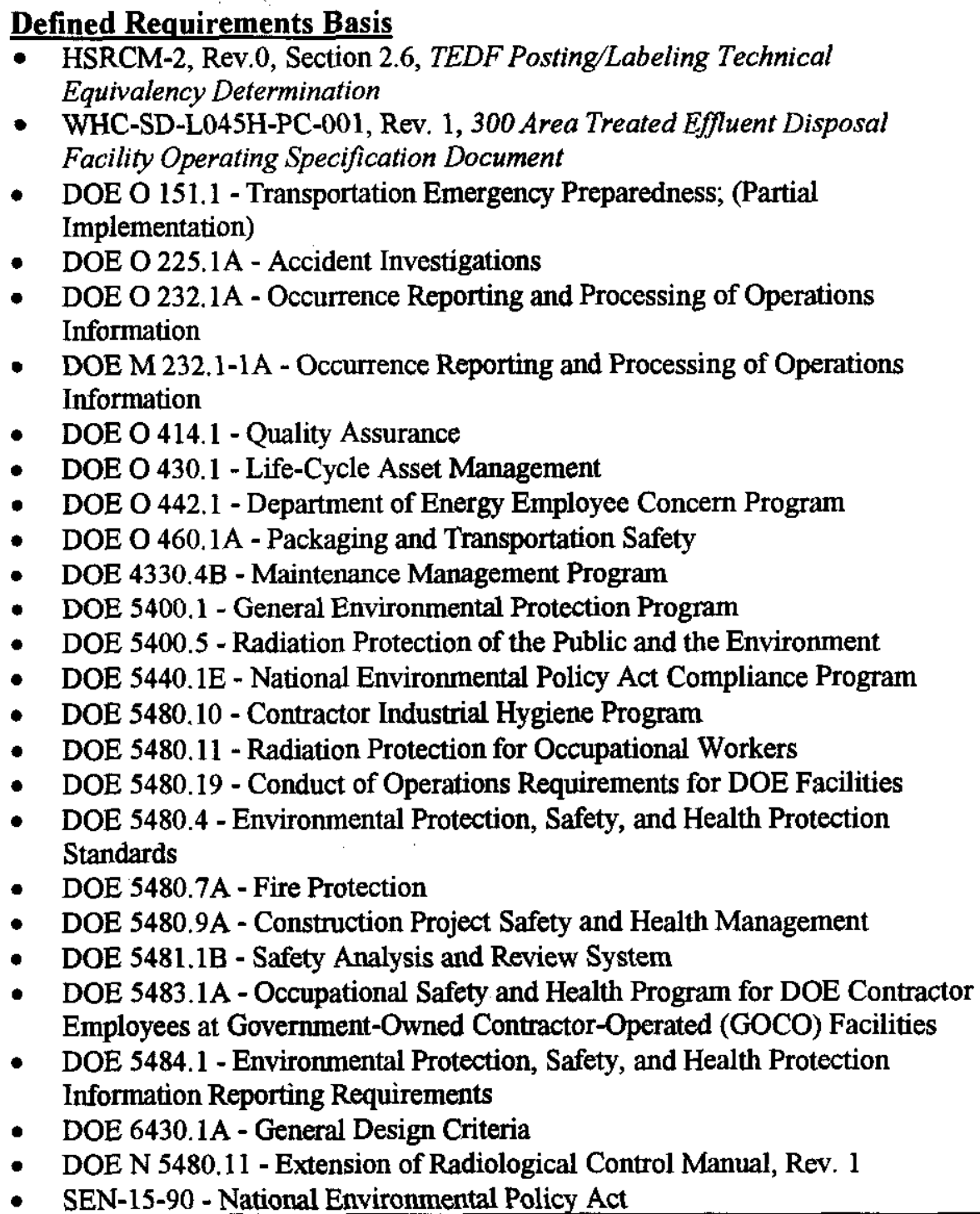 \\
\hline
\end{tabular}




\section{Area Liquid Effluent Facilities Authorization Envelope}

APPENDIX A - Authorization Envelope

Facility: 310 Treated Effluent Disposal Facility

Hazard Categorization: Non-Nuclear, Moderate Hazard

Operated by: River Corridor Project

\begin{tabular}{|c|c|}
\hline & $\begin{array}{l}\text { - } \text { SEN-39-92 - Department of Energy Occupational Safety and Health (OSH) } \\
\text { Incentives Program } \\
\text { - } \quad \text { RLID 232.1 - Occurrence Reporting and Processing of Operations } \\
\text { - } \quad \text { RLID 5480.7 - Fire Protection } \\
\text { - } \quad \text { RLID 5480.19 - Conduct of Operations Requirements for RL } \\
\text { - DOE-0223 - RL Emergency Implementing Procedures } \\
\text { - } \quad \text { DOE/RL-92-36 - Hanford Site Hoisting and Rigging Manual } \\
\text { - DOE/RL-92-49 Radiological Assistance Program Plan - Region } 8 \\
\text { - DOE/RL-96-109 - Hanford Site Radiological Control Manual } \\
\text { - DOE-RL-SOD-INST-L\&T.001 Hanford Site Lockout/Tagout Program } \\
\text { Commitments } \\
\text { - WHC-SD-L045H-PLN-004, Rev. 1, 300 Area TEDF NPDES Permit } \\
\text { - Compliance Monitoring Plan } \\
\text { WMH-9856250, Conduct of Operations Applicability Matrix (300 Area } \\
\text { LEF/310) } \\
\text { WMH-9855965 R1, 310 Facility Maintenance Implementation Plan, Rev. } 1\end{array}$ \\
\hline $\begin{array}{l}\text { Environmental } \\
\text { Protection Basis }\end{array}$ & $\begin{array}{ll}\text { Permits } \\
- & \text { NPDES Permit WA-002591-7 } \\
\text { - } & \text { Aquatic Lands Sewer Outfall Lease No. 20-13357 } \\
\text { - } & \text { Revised Form 2, Notification of Dangerous Waste Activities } \\
\text { - } & \text { DOE/EA-0383 FONSI } \\
\text { - } & \text { NEPA Categorical Exclusions } \\
\text { - } & \text { Cultural Resources Review HCRC \#92-300-007 }\end{array}$ \\
\hline
\end{tabular}




\title{
300 Area Liquid Effluent Facilities Authorization Envelope
}

\author{
APPENDIX B - Authorization Envelope
}

Facility: 340 Waste Handling Facility

Hazard Categorization: Category III Nuclear

Operated by: River Corridor Project

\begin{tabular}{|c|c|}
\hline Safety Basis & $\begin{array}{l}\text { Authorization Basis Documentation } \\
\begin{array}{l}\text { HNF-SD-WM-ISB-003, Rev. 2, 340 Waste Handling Facility Interim Safety } \\
\text { Basis }\end{array} \\
\text { Hazard Baseline Documentation } \\
\text { WHC-SD-PRP-HA-021, Rev. 0, 340 Building Hazards Assessment } \\
\text { WHC-SD-SQA-CSA-20379, Rev. 1, Criticality Safety Evaluation Report for } \\
\text { 340 Facility } \\
\text { WHC-SD-WM-FHA-011, Rev. 1, 340 Complex Fire Hazard Analysis }\end{array}$ \\
\hline $\begin{array}{l}\text { ES\&H Requirements } \\
\text { Basis }\end{array}$ & $\begin{array}{l}\text { Defined Requirements Basis } \\
\text { - } \text { HNF-SD-MP-SRID-011, Rev. 0, Waste Management Operations } \\
\text { - DOE O 151.1 - Transportation Emergency Preparedness; (Partial } \\
\text { Implementation) } \\
\text { - DOE O 225.1A - Accident Investigations } \\
\text { - DOE O 232.1A - Occurrence Reporting and Processing of Operations } \\
\text { Information } \\
\text { - DOE M 232.1-1A - Occurrence Reporting and Processing of Operations } \\
\text { Information } \\
\text { - DOE O 414.1 - Quality Assurance } \\
\text { - DOE O 430.1 - Life-Cycle Asset Management } \\
\text { - DOE O 442.1 - Department of Energy Employee Concern Program } \\
\text { - DOE O 460.1A - Packaging and Transportation Safety } \\
\text { - DOE 4330.4B - Maintenance Management Program } \\
\text { - DOE 5400.1 - General Environmental Protection Program } \\
\text { - DOE 5400.5 - Radiation Protection of the Public and the Environment } \\
\text { - DOE 5480.1E - National Environmental Policy Act Compliance Program } \\
\text { - DOE 5480.11 - Radiation Protection for Occupational Workers } \\
\text { - DOE 5480.19 - Conduct of Operations Requirements for DOE Facilities } \\
\text { - DOE 5480.20A - Personnel Selection, Qualifications, and Training } \\
\text { - Requirements for DOE Nuclear Facilities } \\
\text { - DOE 5480.21 - Unreviewed Safety Questions } \\
\text { - DOE 5480.22 - Technical Safety Requirements } \\
\text { - DOE 5480.23 - Nuclear Safety Analysis Reports } \\
\text { - DOE 5480.24 - Nuclear Criticality Safety } \\
\text { - DOE 5480.28 - Natural Phenomena Hazards Mitigation } \\
\text { - DOE 5480.31 - Startup and Restart of Nuclear Facilities } \\
\text { - Standards - Environmental Protection, Safety, and Health Protection } \\
\text { - DOE 5480.7A - Fire Protection } \\
\text { - DOE 5480.9A - Construction Project Safety and Health Management } \\
\text { DOE 5483.1B - Safety Analysis and Review System } \\
\text { Employees at Government-Owned Contractor-Operated (GOCO) Facilities }\end{array}$ \\
\hline
\end{tabular}




\section{Area Liquid Effluent Facilities Authorization Envelope}

APPENDIX B - Authorization Envelope

\section{Facility: 340 Waste Handling Facility \\ Hazard Categorization: Category III Nuclear \\ Operated by: River Corridor Project}

\begin{tabular}{|c|c|}
\hline & 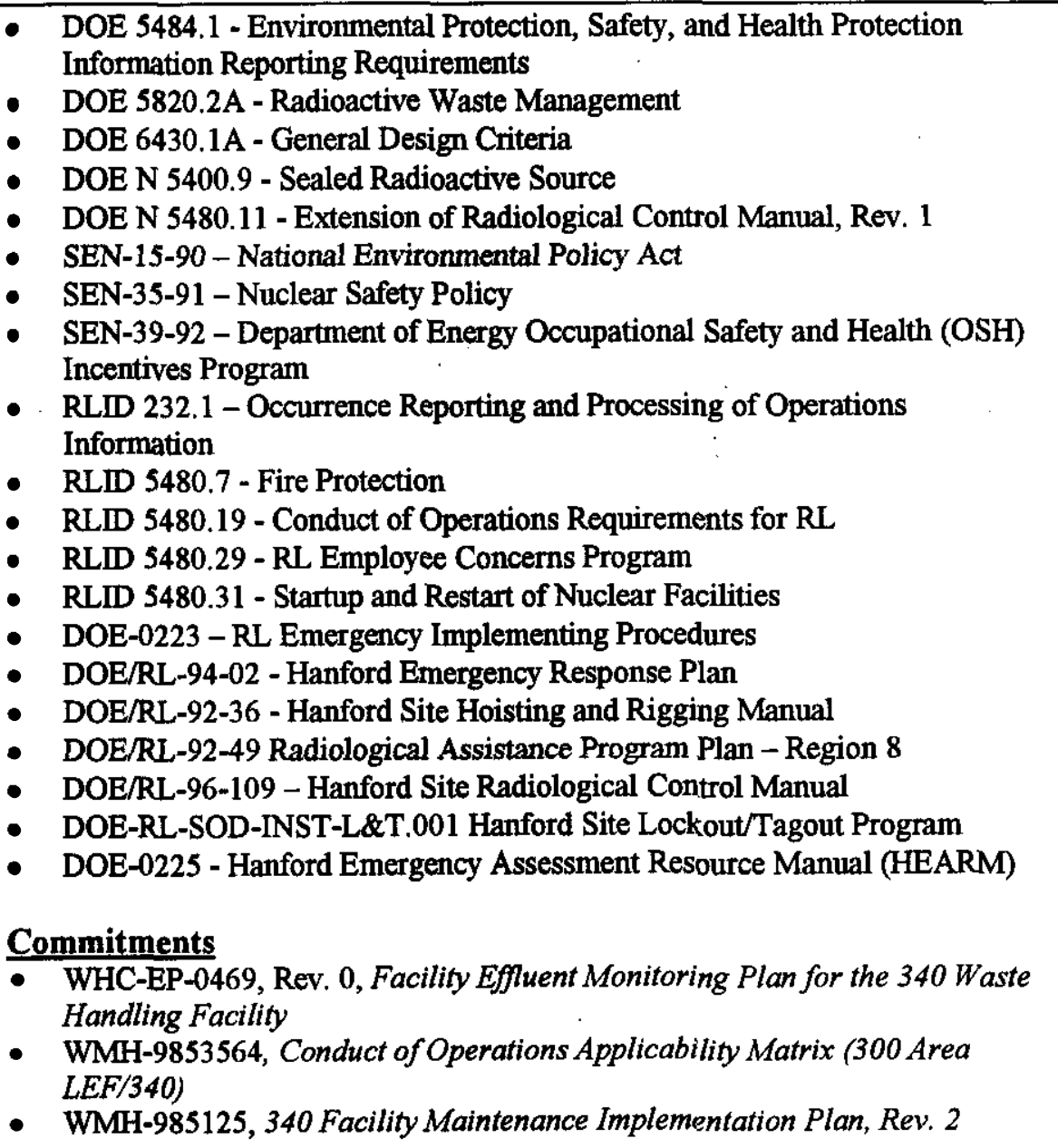 \\
\hline $\begin{array}{l}\text { Environmental Protection } \\
\text { Basis }\end{array}$ & $\begin{array}{l}\text { Permits } \\
\text { - DOE/RL-97-06, Rev. 0, Radioactive Air Emissions Notice of Construction } \\
\text { 340A Building } \\
\text { - } \\
\text { DOE/RL-97-15, Rev. 0, Nonradioactive Air Emissions Notice of Construction } \\
\text { - Notice of Construction - AIR 97-604 for Tank Solid Removal } \\
\text { - Revised Form 2, Notification of Dangerous Waste Activities } \\
\text { - NEPA Categorical Exclusions } \\
\text { - Notice of Construction, Isolation of Radioactive Liquid Waste System Line in } \\
\text { Valve Box } 11 \text { Outside the } 324 \text { Facility - Approved 7/7/99 } \\
\text { - State of Washington Department of Health Radioactive Air Emissions Permit, } \\
\text { FF-01 } \\
\text { - Hanford Site Air Operating Permit Application, as amended, DOE/RL-95-07, } \\
\text { May } 1995 \\
\text { - Draft Hanford Site Air Operating Permit, HNF-AOP-97-1, } 1998\end{array}$ \\
\hline
\end{tabular}

